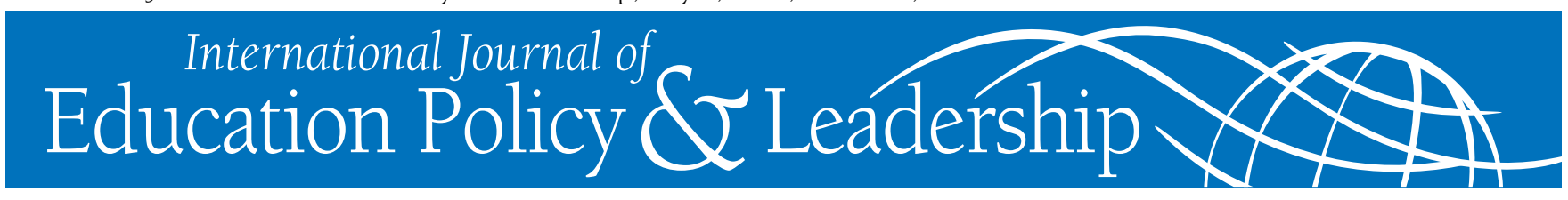

\title{
Research Courses in Education Leadership Programs: Relevance in an Era of Accountability
}

\author{
REBECCA M. BUSTAMANTE \\ Sam Houston State University \\ Julie P. COMBS \\ Sam Houston State University
}

\begin{abstract}
Master's degree research course offerings of 72 university education leadership programs were examined to explore how relevant the courses were to the inquiry needs of practicing school leaders. Research course titles and descriptions were analyzed using content analysis. Findings revealed considerable variation in research course requirements, course titles, and course descriptions. Analysis of course descriptions indicated minimal emphasis on the research skills required for school improvement. Results also suggested a lack of consensus on the importance of developing research skills for school leaders across university education leadership programs. Implications for education leadership preparation programs are discussed with an emphasis on the need for further studies on the research skills required by practicing school leaders.
\end{abstract}

Bustamante, R. M. \& Combs, J. P. (2011). Research Courses in Education Leadership Programs: Relevance in an Era of Accountability. International Journal of Education Policy and Leadership 6(3). Retrieved [date] from http://www.ijepl.org.

In a recent research report released by the Organization for Economic Cooperation and Development (OECD) that studied education leadership in 22 nations, school leadership improvement was described as a worldwide challenge. National school systems around the globe are struggling to attract and retain school leaders who can effectively respond to the expanding roles and responsibilities of school leadership (Pont, Nusche, \& Moorman, 2008). In the United States, national research reports have focused on a need to improve school leadership preparation programs (Darling-Hammond, LaPointe, Meyerson, \& Orr, 2007; Levine, 2005), while scholars in the field of education leadership have emphasized that preparation program improvement is essential to overall school improvement (Murphy, 1999, 2002; Scribner \& Bredeson, 1997). Furthermore, education leadership researchers have suggested that conventional principal preparation programs were not aligned with the knowledge, skills, and behaviors required by principals to function effectively on a day-to-day basis (English, 2006; Fossey \& Shoho, 2006; Hess \& Kelly, 2007). In general, preparation programs for school administrators have been criticized for being deficient in several areas, including recruitment of quality candidates, collaboration between university faculty and practitioners, and relevant curriculum (Jackson \& Kelley, 2002). This impetus for universities to provide relevant curriculum and instruction has become increasingly urgent as privatization and alternative principal preparation programs compete with traditional university programs for student enrollment. Despite this call for program relevance, limited studies are available that closely examine master's degree courses in school administration, and, in particular, that ana-

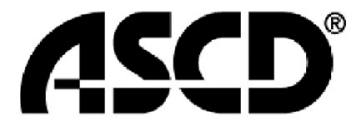

LEARN. TEACH. LEAD.
SIMON FRASER UNIVERSITY THINKING OF THE WORLD

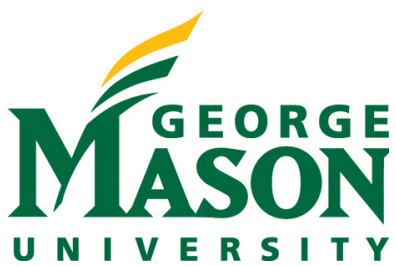


lyze the content and relevance of master's-level research courses for school principal candidates.

The need for a closer examination of the content and relevance of the research courses required in master's-level education leadership programs is evident. In general, school leaders around the world are under tremendous pressure to meet the demands of increasing academic accountability and high-stakes standardized testing (Pont et al., 2008). That is, school leaders are called upon to apply inquiry skills in leadership decision making and, essentially, make what is often rhetorically referred to as data-based decisions. Moreover, in the United States, school leaders are required to analyze programs for evidence of scientifically based research-a term that occurs more than 100 times in the federal No Child Left Behind Act (Hess \& Petrilli, 2006). To make decisions dependent on research or data, school leaders must develop an inquiry-oriented perspective and be trained in how to gather, analyze, and use data to facilitate school improvement and student achievement, while also considering the unique school communities they serve (Lauer, 2006). Education leaders must develop keen, sophisticated research skills that are applicable and relevant to the real, daily challenges of leading successful schools.

Therefore, more empirical studies are needed to examine master's-level research course offerings and content in school administration programs, as well as to analyze the relevance of the research skills taught compared to the actual inquiry competencies required by practicing school leaders. The purpose of this study was to begin to address this research gap by analyzing the course offerings and course content of 72 master'slevel research courses in education leadership and education administration programs. The sampled programs were based in the United States, with the exception of one in Canada and one in Hong Kong. Implications of study results were examined further within the context of professional, policy-dictated standards and academic discussions of course content relevance in university-based principal preparation programs.

\section{Related Literature}

The lack of academic literature and empirical studies on master's-level research courses in the field of education leadership is puzzling at a time when legislation and professional standards require school administrators to make data-based or research-based decisions. These requirements are evidenced by standards developed by the Interstate School Leaders Licensure Consortium (ISLLC). ISLLC was created by members of the U.S. National Policy Board for Educational Administration (NPBEA), who developed Standards for School Leaders in 1996, revised them in 2002 and 2007, and proposed more revisions in 2009. Specifically, these standards have consistently included statements emphasizing that school leaders should be able to use "data-based research strategies" (NPBEA, 2002, p. 2) and apply "data-based decision making" (NPBEA, 2002, p. 10). Combs, Bustamante, and Wilson (2007) analyzed the 2002 standards and located 28 uses of the term research and 15 instances of data. In addition to the ISLLC standards, university education leadership programs in the United States aspire to meet Education Leadership Constituent Council (ELCC) standards developed for the National Council for Accreditation of Teacher Education (NCATE) by the NPBEA and are used as a measure of preparation program quality. The ELCC standards also include references to data-based decision making and the importance of inquiry skills for effective school leadership.

To meet these professional standards as well as federal and state government accountability demands for student standardized test performance, district and school administrators in the United States are consistently called upon to apply research skills in analyzing student achievement data and documenting school improvement efforts. Clearly, education leadership preparation programs might benefit from a closer examination of this apparent disparity between the growing demand for school leaders with research skill competencies and the overall lack of information on university research courses.

Although many accredited education leadership programs in the United States require students pursuing a master's degree to successfully complete a minimum of one research methods course (Onwuegbuzie \& Leech, 2005), little attention has been given to the content of these courses and the actual relevance of research course objectives to the needs of practicing school administrators. In general, few studies have analyzed how well the content of the research methods course prepares school leaders to apply research skills 
in actual school settings or to be competent consumers of research (Huck, 2008).

Despite this general dearth of research available on the content and relevance of master's research courses in education leadership and administration programs, some relevant studies were available for review. Most of these available studies have consisted of some form of descriptive document analysis of research course syllabi, surveys exploring faculty and administrator perceptions of research courses, or content analysis of research textbooks.

\section{Research Course Offerings}

Hess and Kelly (2007) systematically coded 210 core course syllabi from 56 principal preparation programs to examine the content of instruction. Findings revealed that just $2 \%$ of the courses addressed accountability in school management or improvement, and less than 5\% included instruction on managing school improvement using data, technology, or empirical research. In another study, Pohland and Carlson (1993) polled faculty at the 52 UCEA member institutions to determine the extent of curriculum reform in education administration programs. They analyzed 40 institutions and their list of courses, number of required credit hours, and level of study (i.e., masters, doctoral). Research courses were ranked eighth in a frequency list of 23 course titles and were offered by $70 \%$ of the institutions, with a majority of the courses (83\%) equaling 3 credit hours.

Pohland and Carlson (1993) categorized the research courses into at least one of five categories including general research courses (17.5\%), quantitative (12.5\%), qualitative (30\%), research in education administration (42.5\%), and miscellaneous (12.5\%). Those in the general category included titles such as Introduction to Research and Research Designs. Quantitative courses included those relating to statistics. The miscellaneous category included examples such as Survey Research and Philosophic Inquiry. The authors noted some research offerings had changed, and institutions were shifting from a heavy emphasis on statistics to a greater number of courses focused on qualitative approaches. Based on the review of course titles, the authors concluded that although changes were occurring in education administration programs, the changes were "gradual and incremental rather than radical and immediate" (Pohland \& Carlson, 1993, p. 8). Similar studies on research courses and education leadership programs were not located even when using numerous search terms, databases, and search engines.

\section{School Leader Perceptions of Research Courses}

Exploring school leader perceptions of research courses, Combs et al. (2007) examined the NPBEA standards and located references to research-related skills. In addition, practicing education leaders completed a questionnaire about their graduate research course experience. When asked to recall the content of the research course, most administrators remembered how to identify a research design, how to cite existing literature, and how to compare quantitative and qualitative methods. A majority of the comments were centered on various research designs. Although the administrators remembered learning research methods, few reported that they applied the skills in their roles as school leaders or believed them to be of importance. These leaders reported that relevant skills would include collecting data, analyzing data, and critiquing research. Findings also revealed that although school administrators believed that consumer research skills were important, they did not view themselves as qualified to critique or use research in their jobs.

In another study that elicited principal perceptions of research, Haller and Kleine (2001) discovered that few administrators reported using research to impact decision making. Some of the reasons cited were (a) a lack of knowledge in how to access and interpret research studies, (b) a lack of trust regarding research results, (c) a need for immediate answers, and (d) a lack of time required to process the abundance of available information. Yet, superintendents ranked the use of research skills by school principals to be of high importance (Lease, 2002).

\section{Research Textbooks}

Ranis (2003) reviewed textbooks for introductory research courses and collected survey data from education administration graduate students. She reported that the reviewed textbooks rarely addressed research challenges in education and presented few examples of applied education research. Ranis (2003) suggested 
that relevant examples of education research were applied inconsistently in research textbooks. Two of the textbooks reviewed dedicated nearly $40 \%$ of their chapters to the presentation of research design procedures. Almost one half of the administrators and teachers enrolled in a research methods course reported they were not interested in learning more about research methods and over 90\% were not interested in taking additional courses in research methods. Ranis concluded that a gap existed between the perceptions of university faculty and education leadership students regarding the necessary learning objectives of the research course. This gap in perceived needs might have influenced the participating educators' lack of interest in taking additional research courses.

There is a need for further research exploring potential gaps between research course offerings and the needs and interests of master's degree candidates in school leadership and administration. To further these efforts, this exploratory study aimed to uncover the focus and content of research courses in education leadership and administrator programs by examining master's research course offerings, titles, and descriptions of University Council of Educational Administration (UCEA) member institutions.

Four principal research questions guided this inquiry:

1. How many research courses are typically required in the education leadership master's degree programs at UCEA institutions?

2. What are the required research courses in the education leadership master's degree programs at UCEA institutions?

3. How do UCEA institutions describe their research courses?

4. To what extent do these research course descriptions reflect the standards for advanced programs in education leadership?

\section{Method}

\section{Sample}

The sample for this study included all institutional members listed on the membership list of the University Council for Educational Administration (UCEA) in 2007 and totaled 78. UCEA is a consortium of research and doctoral granting institutions with the pri- mary purpose of advancing the preparation and practice of education leaders (UCEA, 2007). There were two primary reasons why UCEA institutions purposely were selected for this study. First, the UCEA organization is considered a leader in influencing policy and program development related to the field of education leadership. UCEA's ongoing involvement in the development of the revised education leadership policy standards reflects its role as a leading organization. Second, in a similar study 15 years ago, researchers examined research courses in education leadership using UCEA member institutions in their sample (Pohland \& Carlson, 1993), providing some basis for trend comparison.

\section{Data Collection}

Research course offerings, titles, and descriptions from the identified university programs were gathered by searching program websites. Degree plans were located to determine the minimum number of required research coursework for the master's degree. Specifically, we searched a variety of locations including the education leadership department's website, the college's website, the university catalog, the graduate school catalog, and the course registration system to locate the requirements for a master's degree in education leadership. Course titles, descriptions, and credit hours for research or research-related courses (i.e., statistics) were copied and pasted into a spreadsheet to organize data for analysis. Of the 78 institutions in the sample, two were eliminated because of inoperable websites and four were eliminated because the institutions did not display course requirements on their websites, leaving 72 institutions.

\section{Data Analysis}

Classical content analysis was determined to be the most appropriate approach to analyzing the data on research course offerings because the technique allowed for inferences to be made by objectively and systematically identifying specified characteristics of text (Berelson, 1952; Krippendorf, 2004). Classic content analysis essentially involves a systematic analysis of text to extract patterns and symbols of meaning to allow researchers to infer or predict phenomena that cannot be observed easily (Krippendorf, 2004). Krip- 
pendorfs questions and coding procedures provided an applicable general framework for analyzing the content of research course titles and course descriptions. Additionally, the methods of constant comparison (Glaser \& Strauss, 1967) and horizonalization (Moustakas, 1994) were utilized to enhance credibility and inter-coder agreement. To do this, we read and reread each research course description and then unitized them.

Data were analyzed in several phases. First, the number of actual courses required by each master's program in education leadership was determined. Second, course titles were analyzed for word frequencies and then categorized as they related to educationspecific or non-discipline specific research courses. Third, the keywords were collapsed into similar semantic categories (e.g., research methods, research designs) based upon the words contained in the course title. The categories identified included generic research courses (i.e., Research Methods, Research Design) course titles using the word education, and titles containing words pertaining to school leaders or education administrators. Next, course titles were categorized by research approaches suggested in the title such as quantitative research, qualitative research, statistics, program evaluation, and action research. Titles suggesting school improvement, data analysis, or inquiry were also noted. In all, 11 categories were created and each title was coded a " 1 " if the title contained the theme and a " 0 " if it did not. Categories were not exclusive and some titles represented several themes. Finally, categories were summed and described using frequency counts and percentages.

A similarly iterative process was followed for the analysis of course descriptions. Specifically, key words and phrases for each description were highlighted. This served as a basis for extracting a list of nonrepetitive, nonoverlapping significant statements (i.e., horizonalization of data; Moustakas, 1994), with each statement being given equal weight. Units were eliminated that contained the same or similar statements or key words so each analyzed unit corresponded to a unique response. Meanings then were formulated by extracting the meaning of each significant statement. Next, these significant statements were compared to previous codes so that similar clusters were labeled with the same code. After all the responses had been coded, the codes were grouped by similarity, and a theme was identified and outlined based on each grouping. That is, the aggregate formulated meanings were organized into emergent themes and subthemes, with each theme and subtheme consisting of units that were deemed similar in content.

Using this process of analysis for inter-coder reliability, we grouped related terms into 12 initial classifications which were (a) basic research methods, (b) basic concepts and terms, (c) data collection, (d) education research, (e) education leadership, (f) research process, (g) writing, (h) independent projects, (i) research tools, (j) consumption of research, (k) school improvement, and (l) real-world applications. The course description data were then set aside and reexamined after a 2-month period.

Then, we determined that the initially identified categories could be further collapsed into six themes: (a) basic research concepts (i.e., methods, terms, data collection); (b) tools for research (i.e., library searches, statistics, computer programs, and writing); (c) independent research projects; (d) consumption of research; (e) education research (e.g., reference to real world situations in an education context); and (f) education leadership (i.e., administration, program evaluation, and school improvement). The basic research concepts theme included all references to terms and processes that could be applied in social and behavioral sciences, regardless of the specific discipline. The tools theme was created after consulting Leedy and Ormrod's (2005) description of research tools that are used by researchers to make meaning of collected data and are not discipline-specific. Leedy and Ormrod included library resources, computer applications, statistics, and writing in their definition of research tools. Some universities solely described the development of an independent research project as the course requirement and others included a research project in their overall course descriptions. For this reason, independent research project was identified as a theme and coded accordingly. Course descriptions that referred to preparing students to be consumers of research were coded as the theme of consumption. The theme education research included all direct references to education and action research in schools or classrooms. Finally, education leadership and administration included course descriptions that included these terms in addition to school improvement or evaluation as education leaders normally take on these functions. 
For each of the course descriptions, a "0" (no mention of terms related to theme category) or "1" (reference to a theme-related term) was given for each of the six thematic categories. Coding was not mutually exclusive as course descriptions could receive a " 1 " in various categories. Frequencies and percentages for each thematic category were then determined.

Additionally, an analysis of standards for education leadership programs (NPBEA, 2002) described in a previous study (Combs et al., 2007) was reviewed and compared to revised standards, Education leadership Policy Standards: ISLLC 2008 (NPBEA, 2007), and course descriptions. We wanted to examine the extent to which the revised standards for education leadership programs contained language related to use of data, inquiry, and school improvement as compared to the previous standards (NPBEA, 2002). Key phrases were identified in the standards that related to the use of data, research, or inquiry. Then, key phrases were compared to determine similarities and differences in language.

\section{Findings}

\section{Research Course Requirements}

The required credit hours for research courses in a master's degree ranged from 0 to 10 hours as shown in Table 1. Of the 72 institutions, 16 (22.2\%) did not require a research course for students pursuing a master's degree in education leadership. Of the 56 institutions that included a research course in the core curriculum, 42 (58.3\%) called for 3 hours of research coursework and 8 (11.1\%) for 6 credit hours. The remaining five institutions requested that education leadership students take $4,8,9$, or 10 credit hours in research. One institution did not use a credit hour system but did include one research course as part of its

Table 2

Content Analysis of Course Titles of Required Research Courses in Education Leadership Master's Degree Programs at UCEA Institutions 2007

\begin{tabular}{llll}
\hline Theme & $n$ & $\%$ & Example Course Titles \\
\hline Generic & 23 & $31.1 \%$ & Research Methods, Foundations in Research \\
Education & 41 & $55.4 \%$ & Research Design in Education \\
Education leadership & 10 & $13.5 \%$ & Research for Effective School Leaders \\
\hline$(n=74)$ & & & \\
\hline
\end{tabular}

Table 1

Research Course Requirements in Education Leadership Master's Degree Programs at UCEA Institutions 2007

\begin{tabular}{lll}
\hline Research Course Requirements & $\mathrm{n}$ & $\%$ \\
\hline No hours required & 16 & $22.2 \%$ \\
3 credit hours required & 42 & $58.3 \%$ \\
4 credit hours required & 3 & $4.2 \%$ \\
6 credit hours required & 8 & $11.1 \%$ \\
8,9, or 10 credit hours & 3 & $4.2 \%$ \\
\hline$(n=72)$ & &
\end{tabular}

course requirements. The university program that asked students to take 10 hours of coursework had a master's degree program requiring 51 hours. Therefore, these findings suggest that most UCEA institutions require one 3-hour research course in the master's degree program for education leaders.

\section{Course Titles}

For the 56 institutions requiring a research course, 74 research course titles were analyzed and categorized as shown in Table 2. Of the 74 course titles, 23 (31.1\%) were generic research courses, having titles such as Research Methods, Foundations in Research, and Research Design and Methodology. The generic titles were listed with a variety of prefixes, indicating that such courses were taught by faculty in other departments outside of education leadership (e.g., education psychology, math, statistics). Then, course titles were analyzed for their mention of education or education leadership. Of the 74 titles, 41 (55.4\%) specifically mentioned education in the course title, 33 (44.6\%) did not. Some examples of courses specific to education included Research and Educational Practice and Research Design in Education. Of the 41 research courses specific to education, 10 (13.5\%) of the titles contained language specific to education leaders such as Quantitative Methods in Educational Leadership, Research in Educational Administration and Policy, and Research for Effective School Leaders.

The course titles were analyzed for their mention of statistics, quantitative research, 
qualitative research, program evaluation, and action research. Of the 56 institutions requiring a research course, nine required a course in statistics. Interestingly, four of the nine institutions having a statistics course also expected students to take one other research course, while five of the institutions listed the statistics course as its only research course. Of the 56 institutions, six had required research courses related to quantitative methods, five specified qualitative methods, and six had program evaluation in the title. Four institutions, all of which required at least two research courses, offered an action research course. Course titles were also analyzed for less common names. Of the 56 institutions, three offered a course containing inquiry in the title, two mentioned school improvement, and three specified data use or data analysis. In summary, $55.4 \%$ of the course titles specifically mentioned education and $31.1 \%$ had generic research methods titles. Fewer courses (13.5\%) were specific to education leaders.

\section{Course Descriptions}

The 74 course descriptions among the 58 institutions were analyzed and coded using the following six themes: (a) basic research concepts, (b) tools for re- search, (c) independent projects, (d) consumption of research, (e) education research, and (f) research for education leaders and school improvement. The categories were not exclusive, and some course descriptions were coded in multiple categories.

As shown in Table 3, findings revealed that 37 (50.0\%) research course descriptions focused on basic research concepts, 30 (40.5\%) referred to education or schools in their descriptions of the research course, and $23(31.1 \%)$ described the use of tools in the course. Moreover, 16 (21.6\%) of the research course descriptions actually contained the term education leadership or school improvement, and both consumption of research (8.1\%) and independent research projects $(8.1 \%)$ were mentioned six times in research course descriptions.

Two of the universities reviewed were located outside the United States. Their course descriptions contained terms such as education research and education leadership. These international universities appeared to be negative cases when compared to the other institutions due the thoroughness of their course descriptions and their specific reference to the development of research skills for education leadership and school improvement. These negative cases were retained in the analysis.

Table 3

Content Analysis of Research Course Descriptions

\begin{tabular}{|c|c|c|}
\hline Theme & Example Statements from Description & Frequency \\
\hline Basic Research Concepts & $\begin{array}{l}\text { "development of basic skills in understanding, planning, and } \\
\text { executing a research study" } \\
\text { "issues in research design and methodology" }\end{array}$ & $50.0 \%$ \\
\hline Educational Research & "major modes of inquiry in contemporary educational research" & $40.5 \%$ \\
\hline Tools for Research & $\begin{array}{l}\text { "statistics as a tool in education" } \\
\text { "applying the tools of research to address issues that face school } \\
\text { leaders" }\end{array}$ & $31.1 \%$ \\
\hline $\begin{array}{l}\text { Research for Education } \\
\text { Leadership and/or School } \\
\text { Improvement }\end{array}$ & $\begin{array}{l}\text { "learn how to use data to drive instruction" } \\
\text { "improvement of educational programs" }\end{array}$ & $21.6 \%$ \\
\hline Consumption of Research & $\begin{array}{l}\text { "skills necessary for critical consumption of quantitative re- } \\
\text { search" } \\
\text { "become intelligent consumers of research" }\end{array}$ & $8.1 \%$ \\
\hline $\begin{array}{l}\text { Independent } \\
\text { Projects }\end{array}$ & $\begin{array}{l}\text { "complete a research project or field study" } \\
\text { "complete a paper including an action research plan" }\end{array}$ & $8.1 \%$ \\
\hline
\end{tabular}




\section{Standards for Education Leadership Pro- grams}

The program standards for education leadership (NPBEA, 2007) were analyzed, and several statements were found that specified some research-related expectations of education leaders. Specifically, six phrases were found in the 2007 standards. Leaders were expected to "monitor and evaluate" programs and practices (NPBEA, 2007, II 3, 5, 7); "promote continuous and sustainable improvement" (I 3); "collect and use data to identify goals, assess organizational effectiveness" (II 3); and "collect and analyze data ... pertinent to the education environment" (II 9). The key words we as the researchers selected from these statements were monitor, evaluate, collect, and analyze, and the 74 course descriptions were reviewed to identify the use of these words or their derivatives.

As shown in Table 4, classical content analysis revealed that of the 74 research methods descriptions, 19 (25.6\%) mentioned data analysis, 12 (16.2\%) contained the concept of evaluation, 12 (16.2\%) mentioned the collection or gathering of data, and 3 (4.1\%) referenced monitoring of programs, practices, or both. After analyzing all 74 course descriptions, 30 (40.1\%) mentioned at least one of the key words, which were monitor, evaluate, collect, and analyze. Therefore, less than one half of the research methods courses contained some language related to inquiry skills that appear in the NPBEA standards for education leadership preparation programs.

\section{Discussion}

This exploratory study was designed in response to U.S. policies and professional standards requiring school leaders to be highly qualified in applying research skills in ways that lead to student achievement and overall school improvement. In this study, classical content analysis was applied to review research course offerings, titles, and course descriptions required in master's programs in education leadership or school administration. As a starting place for evaluating the quality of education leadership programs, scholars have used content analysis to examine written program requirements, course descriptions, and syllabi (Hackmann \& Wanat, 2007; Hess \& Kelly, 2007).

Likewise, as a first step in exploring research offerings and research course content in master's programs in education leadership, we employed a similar approach. Implications from this study are relevant to several areas that impact education leadership programs. These areas include policymaking and professional standards for accreditation, program curriculum offerings, and relevance of research course objectives and content as revealed by the language used in course descriptions.

Both U.S. government accountability policies and professional standards in the field of education leadership require that school leaders use research data in making decisions that influence student achievement and overall school improvement. The focus on accountability in the United States became more stringent in 1965 with the enactment of the Elementary and Secondary Education Act, which was reauthorized by President George Bush as the No Child Left Behind Act of 2001. President Barack Obama's administration continues to support the act as accountability and research-based instruction continue to play a large role in Obama's state fund competition as exemplified by the Race to the Top program.

In addition to government accountability policies, the professional NPBEA standards call for the preparation and development of education leaders who are inquiry-oriented and capable of making research-based decisions. The professional standards stipulated by the ELCC and the NCATE form a basis for judging whether U.S. colleges of education and master's degree programs in education leadership receive national accreditation. Consequently, the need for policy makers and program coordinators to examine research course requirements and offerings in master's degree pro-
Table 4

Classical Content Analysis of NCPEA Standards in Research Course Descriptions

\begin{tabular}{lll}
\hline Code & Examples & Frequency \\
\hline Analyze data & "data analysis" & $25.6 \%$ \\
Evaluate programs \& practices & "planning and program evaluation" & $16.2 \%$ \\
Collect/Gather Data & "data gathering" "data collection" & $16.2 \%$ \\
Monitor programs \& practices & "data relevant to monitoring" & $4.1 \%$ \\
\hline Note. Categories are not mutually exclusive & \\
\hline
\end{tabular}


grams in education leadership increasingly is evident. Furthermore, education leadership programs might benefit from national, state, and university policies and professional standards that explicate more clearly the research knowledge and skills most needed for practicing school leaders to positively impact school improvement.

Results from this research were also relevant to master's program curriculum in education leadership. We discovered that the majority of university programs sampled in this study required at least one research course as part of the core curriculum. Because of the limited number of courses offered within a master's program and the required number of courses needed to meet principal certification standards, one research course typically is all that can be offered. Additionally, some program coordinators design their education leadership master's courses to integrate research skills throughout a course sequence by requiring various field projects that include skills related to data analysis, data collection, and program evaluation. However, in this study, we did not examine other course descriptions and this type of coordination among courses was not explicated in the research course descriptions. Following, it can be difficult to determine to what extent research skills are integrated throughout other courses in an education leadership curriculum. Overall, based on this study and previous research (Combs et al., 2007; Ranis, 2003), we propose that the number of research courses offered is of lesser concern than the relevance of the research knowledge and skills to the work of practicing school leaders.

Indeed, one research course offering might be sufficient if the content is focused on relevant inquiry skill development and the language used in course descriptions reflects a specific focus on education leadership. However, results from this study revealed great inconsistencies in the language used in research course descriptions. Few course descriptions contained language specific to the responsibilities of today's school leaders. In fact, only 16 of the 74 education leadership programs included in our sample used the terms school leadership or school improvement in their research course descriptions. Furthermore, many of the research course descriptions were so generic that they could be applied to any social science discipline. Additionally, many of the required research courses were housed in departments other than the college of edu- cation, such as math departments, or taught by faculty from other disciplines not related to education. Both generic course descriptions and research courses offered outside the education leadership program imply that some program coordinators and professors believe that one generic course in traditional research methods adequately equips candidates for the kind of research competencies needed to lead effective schools.

Promising was the fact that just over one half of the research course titles reviewed did include the term education. Use of the term education in the title indicated that research skills might more likely be explored within an education context. However, research course titles in education leadership should not only refer to education, but also demonstrate a clear connection to education leadership. Even when course titles and descriptions in this study did refer to the context of education, it was unclear how much emphasis actually was placed on research competencies required of effective leaders. These competencies would likely include the ability to critically analyze existing data, competently consume research, assess organizational cultures and climates for diverse constituencies, develop survey instruments, evaluate programs, analyze existing achievement data, and determine teachers' professional development needs.

Research courses cannot be a panacea for the betterment and relevance of master's programs in education leadership. In addition, program coordinators rarely have the luxury of adding additional courses to an already full curriculum. The implications of this study relate to what can be inferred from course titles and descriptions. Because university professors frequently rely on course titles and descriptions to guide the planning of course content, activities, and assessments, the findings from this study call attention to the need to use inquiry-oriented language that reflects the needs and required skills of education leaders.

In particular, course descriptions drive the planning of adjunct professors, lecturers, or contingency faculty who might have little direct contact with the university and who typically rely on course descriptions, textbooks, and previous course syllabi to plan their classes. Inadequate, misleading, or generic course descriptions that do not sufficiently address the research skills required of education leaders could influence professors' decisions about course content and the need to provide relevant application for school 
leaders. Consequently, education leadership departments should examine what is and is not included in the course descriptions and consider how inquiryrelated knowledge is situated in school contexts.

Implications for future research include a need to replicate this study with a larger sample of education leadership programs. Programs offering alternative routes to leadership certification should be examined to identify the curriculum prescribed for leaders related to data analysis and applied research skills. In addition, researchers could describe what is actually being taught in research courses through observations and professor self-reports. Also, there is a need to examine how the research skills applied by education leaders in their daily work in schools compare to faculty members' perceptions of what is important to teach. Comparing these perspectives could provide further insight into how research courses could be more relevant for practicing school leaders. Such knowledge could be used to address the gap between university faculty and education leaders' perceptions of the necessary research skills (Ranis, 2003).

Limitations to this study include an acknowledgement that course titles and descriptions might not reveal what is actually taught in a research class or how relevant a professor might make course material to the practice of education leadership. However, the focus of this research was at the organizational level (i.e., master's degree requirements for education leadership candidates); thus examining course descriptions was deemed to be more appropriate than examining individual professors' course syllabi. Further, the method of examining documents (i.e., descriptions, textbooks, syllabi) has been applied by previous researchers (e.g., Hess \& Kelly, 2007; Onwuegbuzie \& Leech, 2005; Ranis, 2003) when analyzing content. Another limitation involves the use of websites. Information used in this study was gathered from university websites; however, websites do not always contain updated information about program requirements and course descriptions. Finally, the research courses provided by institutions in this study might not represent those at other education leadership preparation programs. Although these limitations have been noted, there were few studies where researchers have analyzed research courses for school leader candidates. Thus, this study represents an attempt to engage uni- versity faculty and school leaders in a discussion about the relevance of research courses.

In an era when education policies dictate that school leaders use data to monitor and to improve the learning of all students, graduate programs in education leadership must ensure that required research courses truly provide leaders with the necessary research tools to perform their jobs. Understanding research course offerings and requirements is a critical step in promoting the relevant instruction and quality preparation of future school leaders.

\section{References}

Berelson, B. (1952). Content analysis in communicative research. New York, NY: Free Press.

Combs, J. P., Bustamante, R. M., \& Wilson, E. D. (2007). Research skills for effective school leadership: School administrator perceptions. In L. K. Lemasters \& R. Papa (Eds.), At the tipping point: Navigating the course of the preparation of educational administrators (pp. 310-318). Lancaster, PA: Proactive.

Darling-Hammond, L., LaPointe, M., Meyerson, D., \& Orr, M. (2007). Preparing school leaders for a changing world: Executive summary. Stanford, CA: Stanford University, Stanford Education leadership Institute.

English, F. W. (2006). The unintended consequences of a standardized knowledge base in advancing education leadership preparation. Educational Administration Quarterly, 42, 461-472.

Fossey, R., \& Shoho, A. (2006). Education leadership preparation programs: In transition or in crisis? Journal of Cases in Education leadership, 9(3), 311.

Glaser, B. G., \& Strauss, A. L. (1967). The discovery of grounded theory: Strategies for qualitative research. Chicago, IL: Aldine.

Hackmann, D. G., \& Wanat, C. L. (2007). Licensing principals: Iowa's preparation reform initiative. Journal of Research in Leadership Education, 2(3). Retrieved from http://www.ucea.org/jrle_2007_2_3\%20/

Haller, E. J., \& Kleine, P. F. (2001). Using educational research: A school administrator's guide. New York, NY: Addison Wesley Longman. 
Hess, F. M., \& Kelly, A. P. (2007). Learning to lead: What gets taught in principal-preparation programs. Teachers College Record, 109, 294-274.

Hess, F. M., \& Petrilli, M. J. (2006). No child left behind: Primer. New York, NY: Peter Lang.

Huck, S. W. (2008). Reading statistics and research (5th ed.). Boston. MA: Pearson.

Jackson, B. L., \& Kelley, C. (2002). Exceptional and innovative programs in education leadership. Educational Administration Quarterly, 38, 192-212.

Krippendorf, K. (2004). Content analysis: An introduction and its methodology (2nd ed.). London: Sage.

Lauer, P. A. (2006). What principals need to know about education research. Principal, 85(5) 12-17.

Lease, A. J. (2002). New administrators need more than good grades. School Administrator, 59, 40-41.

Leedy, P. D., \& Ormrod, J. E. (2005). Practical research: Planning and design (8th ed.). Upper Saddle River, NJ: Pearson.

Levine, A. (2005). Educating school leaders. Washington, DC: The Education Schools Project.

Moustakas, C. (1994). Phenomenological research methods. London: Sage.

Murphy, J. (1999). Educational administration: A decade of reform. London: Paul Chapman Publishers.

Murphy, J. (Ed.). (2002). The education leadership challenge. Redefining leadership for the 21st century. Chicago, IL: University of Chicago Press.

National Policy Board for Educational Administration. (2002). Standards for advanced programs in education leadership for principals, superintendents, curriculum directors, and supervisors. Retrieved from http://www.npbea.org/ELCC/ELCCStandards\%20_ 5-02.pdf

National Policy Board for Educational Administration. (2007). Education leadership policy standards: ISLLC 2008. Retrieved from http://www.principals.org/s_nassp/sec_inside.asp?C $\mathrm{ID}=1298 \& \mathrm{DID}=56055$
Onwuegbuzie, A. J., \& Leech, N. L. (2005, March 10). A typology of errors and myths perpetuated in educational research textbooks. Current Issues in Education [On-line], 8(7). Retrieved from http://cie.asu.edu/volume8/number7/

Pohland, P. A., \& Carlson, L. T. (1993). Program reform in educational administration. UCEA Review 34(3), 4-9.

Pont, B., Nusche, D., \& Moorman, H. (2008). Improving school leadership, Volume 1: Policy and practice. Paris, France: Organisation for Economic Cooperation and Development (OECD).

Ranis, S. H. (2003, April). Needing to know: Education leadership preparation and research literacy. Paper presented at the annual meeting of the American Educational Research Association, Chicago, IL. (ERIC Document Reproduction Service No. ED478254)

Scribner, J. P., \& Bredeson, P. V. (1997). Beyond simulations and case studies: Improving leader preparation through Action Research. Journal of School Leadership, 7, 230-245.

University Council for Educational Administration. (2007). UCEA membership policy and procedures. Retrieved from http://www.ucea.org/

IJEPL is a joint publication of the Association for Supervision and Curriculum Development, the Faculty of Education at Simon Fraser University, and the College of Education and Human Development at George Mason University. By virtue of their appearance in this open access journal, articles are free to use, with proper attribution, in educational and other non-commercial settings 90 days after initial publication. Copyright for articles published in IJEPL is retained by the authors. More information is available on the IJEPL Web site: http://www.ijepl.org 